\title{
UPAYA MENINGKATKAN KEMAMPUAN MOTORIK HALUS ANAK MELALUI KEGIATAN MERONCE DARI BAHAN ALAM BIJI HANJELI
}

\author{
Erna Roostin \\ STKIP Sebelas April Sumedang \\ ernaroostin72@gmail.com
}

\begin{abstract}
ABSTRAK
Penelitian ini dilatarbelakangi oleh rendahnya kemampuan motorik halus anak, sehingga dirasa perlu menciptakan suatu kegiatan pembelajaran yang efektif untuk meningkatkan kemampuan motrik halus tersebut. Salah satu upaya yang dilakukan adalah melalui kegiatan meronce dari bahan alam biji hanjeli. Tujuan dari penelitian ini adalah mendeskripsikan kemampuan motorik halus anak melalui kegiatan meronce dari bahan alam biji hanjeli pada anak kelompok A usia 4-5 tahun, metode yang digunakan adalah Penelitian Tindakan Kelas (PTK) dengan menggunakan desain yang dikembangkan oleh Kemmis dan Mc Taggart terdiri dari empat komponen yaitu: perencanaan, tindakan, observasi, dan refleksi. Penelitian ini dilakukan secara daring (online) dan instrument yang dilakukan yaitu berupa lembar unjuk kerja kemampuan motorik halus anak. Berdasarkan hasil penelitian tindakan kelas ini adalah melalui kegiatan meronce dari bahan alam biji hanjeli kemampuan motorik halus anak kelompok A Kober Aulia Desa Gendereh Kecamatan Buahdua Kabupaten Sumedang tahun pelajaran 2019/2020 dapat ditingkatkan. Hasil akhir pada siklus II menunjukan persentase yang mencapai target kemampuan motorik halus adalah 92\%, dengan rata-rata skor kemampuan motorik halus anak secara klasikal mencapai 3,5 dengan kategori berkembang sangat baik (BSB).
\end{abstract}

Kata kunci: Kemampuan Motorik Halus, Kegiatan Meronce

Received 20-10-2021; Received in revised form 31-12-2021; Accepted 31-12-2021

\begin{abstract}
This research is motivated by the low fine motor skills of children, so it is necessary to create an effective learning activity to improve the fine motor skills. One of the efforts made is through activities made from natural ingredients hanjeli seeds. The purpose of this study was to describe children's fine motor skills through meronce activities from natural ingredients hanjeli seeds in group A children aged 4-5 years, the method used was Classroom Action Research (CAR) using a design developed by Kemmis and Mc Taggart consisting of four components, namely: planning, action, observation, and reflection. This research was conducted online and the instrument used was a performance sheet for children's fine motor skills. Based on the results of this classroom action research, through meronce activities from natural ingredients hanjeli seeds, the fine motor
\end{abstract}


J-SANAK: Jurnal Kajian Anak

(p-ISSN: 2686-5343 |e-ISSN: 2715-7989)

Vol. (3)(01), (Juli-Desember)(2021), (Halaman)(12-26)

DOI: https://doi.org/10.24127/j-sanak.v3i01.1514

skills of children in group A Kober Aulia, Gendereh Village, Buahdua District, Sumedang Regency, for the 2019/2020 school year can be improved. . The final result in cycle II showed that the percentage who achieved the target of fine motor skills was $92 \%$, with an average score of children's fine motor skills classically reaching 3.5 with a very well developed category.

Keywords: Fine Motor Skills, Meronce Activity

\section{A. PENDAHULUAN}

Anak usia dini merupakan individu yang unik, berbeda dan tentunya memiliki karakteristik, potensi, kelebihan, kekurangan dan minat masing-masing sesuai dengan tahapan perkembangan, perlu kita sadari bahwa masa-masa awal kehidupan anak merupakana masa terpenting dalam rentang kehidupan seorang anak, pada masa ini stimulasi seluruh aspek perkembangan memiliki peran penting untuk tugas perkembangan selanjutnya. Pendidikan merupakan modal dasar bagi anak agar menjadi seorang insan yang memiliki kualitas hidup, mengingat pentingnya masa ini maka diperlukan pendidikan yang tepat bagi anak. Lembaga Pendidikan Anak Usia Dini (PAUD) merupakan salah satu sarana untuk memfasilitasi pendidikan anak usia dini.

Penyelenggaraan pendidikan anak usia dini diatur dalam Peraturan Menteri Pendidikan dan Kebudayaan Nomor 137 Tahun 2014 tentang Standar Nasional Pendidikan Anak Usia Dini. Semua aspek perkembangan tersebut penting untuk dikembangkan dengan baik agar anak dapat tumbuh dan berkembang secara optrimal, tidak terkecuali aspek perkembangan fisik motorik. Perkembangan fisik dan motorik tidak dapat dipisahkan karena saling mendukung satu sama lain. Rahman (2002) berpendapat bahwa "Perkembangan fisik adalah landasan bagi perkembangan aspek lainnya, sebab perkembangan fisik akan memberikan pengaruh bagi pengembangan aspek-aspek lainnya”. Prinsip perkembangan motorik anak usia dini yang normal ditunjukan terjadi suatu perubahan baik fisik maupun psikis sesuai dengan masa pertumbuhannya" (Sumantri, 2005)

Sujiono, dkk (2018) mengemukakan bahwa faktor-faktor yang mempengaruhi perkembangan motorik seorang anak, diantaranya faktor genetik, kekurangan gizi, pengasuhan serta perbedaan latar belakang budaya, dan rendahnya berat badan lahir seorang bayi juga dapat mengganggu perkembangan motorik anak.Semua aspek perkembangan tersebut penting untuk dikembangkan dengan baik agar anak dapat tumbuh dan berkembang secara optrimal, tidak terkecuali aspek perkembangan pada fisik motorik.

Berdasarkan observasi yang dilakukan peneliti pada anak Kelompok A di Kober Aulia Desa Gendereh Kecamatan Buahdua Kabupaten Sumedang tahun pelajaran 2019/2020, sebagian besar anak kurang terampil dalam mengembangkan motorik halus, anak-anak masih mengalami kesulitan dalam menggerakan koordinasi tangan dan mata. Karena kegiatan pembelajaran yang digunakan guru 
J-SANAK: Jurnal Kajian Anak

(p-ISSN: 2686-5343 le-ISSN: 2715-7989)

Vol. (3)(01), (Juli-Desember)(2021), (Halaman)(12-26)

DOI: https://doi.org/10.24127/j-sanak.v3i01.1514

dalam mengembangkan motorik halus kurang variatif, hal ini dapat dilihat saat kegiatan pembelajaran anak-anak cenderung malas, tidak bersemangat, dan tidak mau melaksanakan kegiatan seperti mewarnai, menggambar, menggunting, menempel dan lain-lain. Anak juga terlihat kurang tertarik dalam kegiatan pembelajaran karena kreativitas guru dan bahan ajar yang digunakan guru cenderung monoton. Anak masih sering disuruh mewarnai gambar pada majalah, menggunting kertas juga menempel kertas warna pada majalah. Sehingga dalam kegiatan anak cepat bosan dan tidak mau menyelesaikanya. Hal itu menjadi bukti bahwa anak memerlukan sesuatu hal yang dapat memotivasi semangat belajar anak, supaya mereka mau untuk melaksanakan kegiatan pembelajaran tentang motorik halus dengan baik.

Melihat dari permasalahan tersebut maka untuk meningkatkan kemampuan motorik halus anak adalah dengan mengubah kegiatan pembelajaran menjadi lebih menarik dan menyenangkan, sehingga anak merasa tertarik dan menjadi lebih bersemangat dalam mengikuti kegiatan pembelajaran. Salah satu kegiatan yang dapat mengembangkan dan menstimulasi kemampuan motorik halus anak yaitu melalui kegiatan meronce dari bahan alam biji hanjeli. Sedangkan tujuan meronce menurut Mulyani (2007: 32) yaitu sebagai berikut. Melatih konsentrasi anak. ,Merangsang kreativitas anak, Melatih koordinasi mata dan jari anak dan Mengenal konsep warna dan keserasian anak.

Sejalan dengan permasalah yang telah penulis kemukakan di atas, maka tujuan penelitian ini yaitu untuk mendeskripsikan aktivitas pembelajaran dan meningkatkan keterampilan motorik kasar anak di Kelompok B RA Nurul Falah Desa Mekarwangi Kecamatan Lemahsugih Kabupaten Majalengka.

Kesenian bagi anak difungsikan sebagai media mengungkapkan perasaan, ide, gagasan, dan pikiran,. Karyanya adalah alat bermain imajinasi dan komunikasi. Pendidik Anak Usia Dini (AUD) harus memiliki pemahaman seni pada AUD (Hajar Pamadhi dan Evan Sukardi S .2010), agar dapat memunculkan potensi kesenian anak seoptimal mungkin. Seperti juga kegiatan meronce merupakan kegiatan seni yang tepat dalam meningkatkan motorik halus anak, karena anak terlibat langsung melakukan kegiatan. Kegiatan meronce diharapkan agar anak aktif dalam mengikuti kegiatan pembelajaran. Kegiatan meronce menjadikan kegiatan yang menyenangkan dan memberi kesenangan bagi anak, dengan demikian kegiatan meronce dapat melatih otot-otot kecil dan melatih keterampilan gerakan koordinasi mata dan tangan serta dapat mendorong dalam mengembangkan daya imajinasi dan konsentrasi anak yang ada dalam dirinya. Sedangkan menurut Yuriastien, dkk (2009) manfaat permain meronce adalah sebagai berikut. membantu kemampuan motorik halus, melatih koordinasi mata dan tangan. Anak menggunakan kedua tangan dan mata untuk memasukan roncean, sehingga membutuhkan koordinasi mata dan tangan.m eningkatkan 
J-SANAK: Jurnal Kajian Anak

(p-ISSN: 2686-5343 |e-ISSN: 2715-7989)

Vol. (3)(01), (Juli-Desember)(2021), (Halaman)(12-26)

DOI: https://doi.org/10.24127/j-sanak.v3i01.1514

perhatian dan konsentrasi. Ada saat meronce, anak membutuhan perhatian dan konsentrasi saat memasukkan roncean ke dalam lubang dengan tepat.

Pemanfaatan bahan ajar juga memiliki peran penting, salah satu bahan ajar yang dapat digunakan dalam kegiatan meronce yaitu dari bahan alam biji hanjeli. Bahan alam adalah bahan-bahan yang berasal dari alam yang dapat diolah menjadi barang-barang yang bermanfaat. Biji hanjeli yaitu jenis tanaman biji-bijian (serelia) tropika dari suku padi-padian. Biji hanjeli merupakan bahan ajar yang dapat menarik minat anak dalam kegiatan meronce, karena biji hanjeli merupakan bahan alam yang ditanam di sekitar rumah jadi anak bisa mengambil langsung dari pohonnya. Dengan mengambilnya langsung biji hanjeli dari pohonnya memudahkan guru dalam menjelaskan bahan ajar. Kegiatan meronce dengan menggunakan bahan alam biji hanjeli merupakan kegiatan pembelajaran yang dilakukan anak secara langsung dan menyenangkan, karena dengan hasil roncean dari bji hanjeli anak dapat membuat gelang atau kalung.

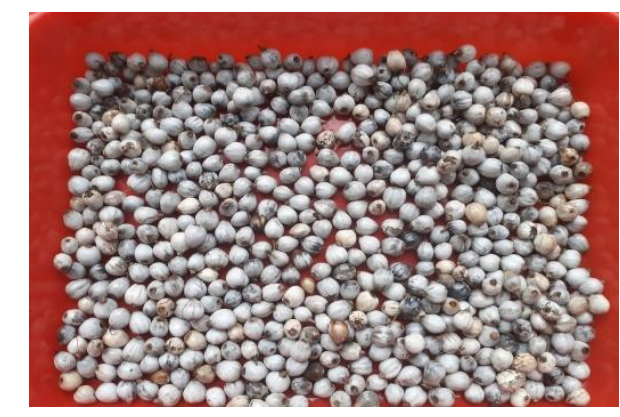

Gambar 1

Bahan Alam Biji Hanjeli

Kegiatan meronce dari bahan alam biji hanjeli ini sangat dibutuhkan untuk meningkatkan kemampuan motorik halus anak, supaya dikemudian hari anak tidak kesulitan dalam setiap kegiatan yang menggunakan koordinasi mata dan tangan. Maka dari itu sudah seharusnya guru dapat memberikan kegiatan pembelajaran yang bervariasi dan menyenangkan dalam pengembangan aspek motorik halus yang dimiliki anak.

Keterampilan motorik berkembang sejalan dengan kematangan syaraf dan otot. Oleh sebab itu, setiap gerakan yang dilakukan anak sesederhana apapun merupakan pola interaksi dari berbagai bagian system dalam tubuh yang dikontrol otak. Sujiono, dkk. (2018) berpendapat bahwa motorik adalah semua gerakan yang mungkin dapatkan oleh seluruh tubuh, sedangkan perkembangan motorik dapat disebut sebagai perkembangan dari unsur kematangan dan pengendalian gerakan tubuh. Samsudin (2007) berpendapat bahwa motorik adalah terjemahan dari kata motor yang berarti suatu dasar biologis atau mekanika yang menyebabkan terjadinya suatu gerak. Gerak adalah kultimasi dari suatu tindakan 
J-SANAK: Jurnal Kajian Anak

(p-ISSN: 2686-5343 |e-ISSN: 2715-7989)

Vol. (3)(01), (Juli-Desember)(2021), (Halaman)(12-26)

DOI: https://doi.org/10.24127/j-sanak.v3i01.1514

yang didasari oleh proses motorik. Yuliansih (Daroyah, dkk 2018) berpendapat bahwa motorik merupakan tindakan yang bisa menimbulkan gerak, dimana semua gerakan yang mungkin dapat dilakukan oleh seluruh tubuh. Dari beberapa pendapat di atas tentang pengertian motorik, dapat disimpulkan bahwa motorik adalah semua gerakan yang dapat dilakukan oleh seluruh tubuh. Adanya keterampilan motorik anak akan menumbuhkan kreativitas dan imajinasi anak. Sedangkan Rini (2018) berpendapat bahwa meronce merupakan bentuk keterampilan merangkai manik-manik menggunakan tali seperti benang, senar dan sebagainya. Keterampilan meronce penting diberikan kepada anak prasekolah seperti Pendidikan Anak Usia Dini (PAUD) karena dapat melatih anak untuk berkonsentrasi. Pada saat meronce anak belajar menggunakan pola dan mengelompokan aneka bentuk. Berdasarkan beberapa pengertian meronce di atas, dapat disimpulkan bahwa meronce merupakan cara pembuatan benda hias atau benda pakai yang dilakukan dengan menyusun bagian bahan yang berlubang yang disatukan dengan tali atau benang.

Pembelajaran di PAUD bahwa meronce adalah kegiatan berlatih berkarya senirupa yang dilakukan dengan cara menyusun bagian-bagian bahan dapat dibuat benda hias atau benda pakai dengan memakai bantuan alat rangkai sesuai dengan tingkat kemampuan anak. Meronce juga termasuk salah satu stimulasi untuk mengasah kemampuan motorik halus anak. Inti dari kegiatan meronce pada penelitian ini yaitu anak bisa memasukkan tali ke dalam biji hanjeli, anak bisa menyusun biji hanjeli sesuai ukuran, anak dapat belajar berhitung dan anak dapat menemukan nama benda hasil dari roncean. Bahan dan alat yang digunakan untuk meronce sangat sederhana.

Meronce tidak hanya menggunakan manik-manik saja, bisa juga menggunakan sedotan untuk bahan roncean. Bahan dan alat yang digunakan juga harus aman untuk anak-anak. Untuk lebih jelasnya bahan dan alat yang digunakan sebagai berikut, Menurut Rini (2018 ) bahan-bahan yang dapat digunakan untuk meronce antara lain sebagai berikut.

1. Bahan alami. Bahan alami adalah bahan yang diperoleh dari alam sekitar, seperti biji-bijian, buah kering, bunga, batang atau cabang kayu, bambu,daun kering dan lain sebagainya.

2. Bahan artifisial (buatan) keras. Yaitu bahan yang terbuat dari bahan buatan, seperti plastic besi fiberglass, formika dan lain sebagainya. Penggunaan bahan artifisial hendaknya dipilih yang aman bagi anak.

3. Bahan artifisial yang lunak-padat, seperi lilin, kue jajan melalui pengukusan,perebusan, pengendapan maupun penggorengan.

Bahan untuk meronce meliputi bahan alam dan bahan buatan. Bahan alam adalah semua jenis bahan yang dapat diperoleh dari lingkungan alam sekitar secara langsung. Contoh dari bahan alam adalah bunga segar, buah-buahan, bunga 
J-SANAK: Jurnal Kajian Anak

(p-ISSN: 2686-5343 |e-ISSN: 2715-7989)

Vol. (3)(01), (Juli-Desember)(2021), (Halaman)(12-26)

DOI: https://doi.org/10.24127/j-sanak.v3i01.1514

kering, daun kering, ranting dan biji-bijian. Sedangkan bahan buatan adalah jenis bahan yang merupakan hasil produk atau buatan manusia, baik berbentuk bahan setengah jadi, bahan jadi atau bahan bekas. Contoh bahan buatan seperti monte, manik-manik, pita sintetis, kertas berwarna, sedotan minuman, plastik. Selain itu ada juga bahan pembantu untuk menambah kesan keindahan hasil rangkaian yang dibuat antar lain berupa lem, tali, benang, cat, pernis dan lainnya, bahan dan alat meronce ada dua macam yaitu bahan alami dan bahan buatan. Bahan dan alat yang digunakan dalam penelitian ini adalah bahan alam yaitu biji hanjeli.

\section{B. METODOLOGI}

Metode yang digunakan dalam penelitian ini adalah Metode Penelitian Tindakan Kelas (PTK) dengan menggunakan desain yang dikembangkan oleh Kemmis dan Mc Taggart yang terdiri dari empat komponen yaitu: perencanaan, tindakan, observasi, dan refleksi. Penelitian ini dilakukan secara daring (online) dan instrument yang dilakukan yaitu berupa lembar unjuk kerja kemampuan motorik halus anak. Arikunto, dkk. (2017) berpendapat bahwa "PTK dapat dikatakan penelitian eksperimen berulang atau eksperimen berkelanjutan, meskipun tidak selalu demikian". Artinya PTK ini dilakukan dalam beberapa tahap, dan tidak dapat diakukan dalam satu kali.

Penelitian tindakan kelas ini dilaksanakan di kelas A Kober Aulia Desa Gendereh Kecamatan Buah dua Kabupaten Sumedang tahun pelajaran 2019/2020. Peneliti melakukan penelitian pada semester II di Kober Aulia Desa Gendereh kecamatan Buahdua Kabupaten Sumedang Tahun Pelajaran 2019/2020 sumber data yang diteliti terdiri dari 12 orang anak usia dini terbagi menjadi 6 perempuan dan 6 laki laki.

\section{Tahap Perencanaan Siklus I}

Pada kegiatan perencanaan penelitian siklus 1 peneliti merancang hal-hal yang perlu dilakukan dalam kegiatan yaitu sebagai berikut.

a. Membuat Rencana Pelaksanaan Pembelajaran (RPP) dan Rencana Pelaksanaan Pembelajaran Harian (RPPH), pada kegiatan penelitian dengan tema diriku sub tema aksesoris topik gelang melalui kegiatan meronce dari bahan alam biji hanjeli.

b. Pembuatan lembar unjuk kerja untuk penilaian dan mengukur peningkatan kemampuan motorik halus anak melalui kegiatan meronce dari bahan alam biji hanjeli.

c. Menginformasikan kepada orangtua melalui whattsapp grup orangtua anak Kober Aulia untuk menyediakan alat dan bahan yaitu biji hanjeli yang sebelumnya sudah peneliti berikan kepada orangtua dengan mengantarkan ke tiap rumah serta media yang dibutuhkan dalam kegiatan yang akan dilaksanakan. Alat dan bahan yang dibutuhkan untuk kegiatan meronce yaitu 
benang dan biji hanjeli. Sedangkan media yang harus dipersiapkan adalah gadget milik orangtua untuk merekam kegiatan yang sesuai dengan apa yang sudah diinformasikan sebelumnya.

Berdasarkan uraian di atas, dapat peneliti simpulkan bahwa hal-hal yang direncanakan dalam siklus I yaitu RPP, RPPH, lembar unjuk kerja untuk menilai peningkatan kemampuan motorik halus anak pada kegiatan pembelajaran, alat dan bahan untuk kegiatan pembelajaran serta media yang berupa hp untuk merekam kegiatan pembelajaran anak.

Ada pun Langkah-langkah penelitian seperti dibawah ini:

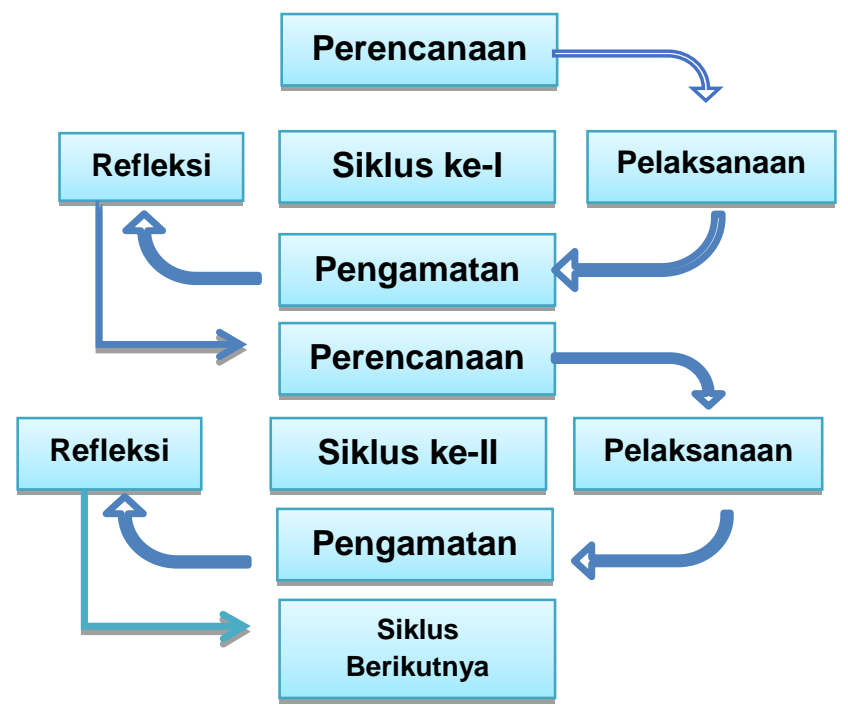

Gambar 2

Desain Penelitian Menurut Kemmis dan Taggart

(Arikunto,dkk. 2015)

\section{HASIL DAN PEMBAHASAN \\ HASIL}

Setelah melakukan pengamatan dan diketahui kondisi awal kemampuan motorik halus anak peneliti melakukan tindakan untuk meningkatkan kemampuan motorik halus anak melalui kegiatan meronce dari bahan alam biji hanjeli. Siklus I dilaksanakan pada hari Selasa, 02 Juni 2020 melalui daring dengan teknik peneliti mengirimkan kegiatan yang harus dilaksanakan oleh anak dengan bantuan orangtua yang merekam melalui gadget terhadap kegiatan itu sendiri. Informasi mengenai kegiatan yang akan dilakukan oleh anak yaitu dikirim peneliti melalui Whattsapp group orangtua Kober Aulia. Sebelum menginformasikan kegiatan kepada orangtua peserta didik, peneliti terlebih dahulu menyusun rencana kegiatan yang dituangkan dalam rencana pelaksanaan pembelajaran harian (RPPH) yang akan peneliti deskripsikan menjadi 4 tahapan diantaranya tahap 
J-SANAK: Jurnal Kajian Anak

(p-ISSN: 2686-5343 |e-ISSN: 2715-7989)

Vol. (3)(01), (Juli-Desember)(2021), (Halaman)(12-26)

DOI: https://doi.org/10.24127/j-sanak.v3i01.1514

perencanaan, tahap tindakan, tahap observasi, dan tahap refleksi. Adapun langkahlangkah tahapannya sebagai berikut.

\section{a. Tahap Perencanaan Siklus I}

Pada kegiatan perencanaan penelitian siklus 1 peneliti merancang hal-hal yang perlu dilakukan dalam kegiatan yaitu sebagai berikut.

1. Membuat Rencana Pelaksanaan Pembelajaran (RPP) dan Rencana Pelaksanaan Pembelajaran Harian (RPPH), pada kegiatan penelitian dengan tema diriku sub tema aksesoris topik gelang melalui kegiatan meronce dari bahan alam biji hanjeli.

2. Pembuatan lembar unjuk kerja untuk penilaian dan mengukur peningkatan kemampuan motorik halus anak melalui kegiatan meronce dari bahan alam biji hanjeli.

3. Menginformasikan kepada orangtua melalui whattsapp grup orangtua anak Kober Aulia untuk menyediakan alat dan bahan yaitu biji hanjeli yang sebelumnya sudah peneliti berikan kepada orangtua dengan mengantarkan ke tiap rumah serta media yang dibutuhkan dalam kegiatan yang akan dilaksanakan. Alat dan bahan yang dibutuhkan untuk kegiatan meronce yaitu benang dan biji hanjeli. Sedangkan media yang harus dipersiapkan adalah gadget milik orangtua untuk merekam kegiatan yang sesuai dengan apa yang sudah diinformasikan sebelumnya.

Berdasarkan uraian di atas, dapat peneliti simpulkan bahwa hal-hal yang direncanakan dalam siklus I yaitu RPP, RPPH, lembar unjuk kerja untuk menilai peningkatan kemampuan motorik halus anak pada kegiatan pembelajaran, alat dan bahan untuk kegiatan pembelajaran serta media yang berupa hp untuk merekam kegiatan pembelajaran anak.

\section{b. Tahap Pelaksanaan Siklus I}

Pelaksanaan tindakan siklus I dilaksanakan pada hari selasa, 02 Juni 2020 yang diikuti semua anak kelompok A Kober Aulia. Dalam pelaksanaan penelitian, seperti yang telah dibahas sebelumnya bahwa penelitian ini dilakukan secara daring (online), sehingga dalam tindakan siklus I peneliti telah menginformasikan kepada orang tua mengenai kegiatan pembelajaran yang akan dilakukan anak melalui whattsapp grup orang tua anak kelompok A Kober Aulia. Orang tua melakukan tindakan sesuai informasi yang diberikan. Adapun uraian kegiatan pada kegiatan meronce dari bahan alam biji hanjeli yaitu orang tua menyiapkan bahan roncean berupa benang dan biji hanjeli. Kemudian orangtua menyuruh anaknya menghitung biji hanjeli, mengelompokan biji hanjeli yang besar dan kecil dan meronce biji hanjeli serta merekam semua kegiatan pembelajaran. Setelah kegiatan pembelajaran selesai, orangtua mengirimkan video dan foto-foto kegiatan anaknya. 
Peneliti bertindak sebagai pengamat yang mengamati hasil kegiatan pembelajaran peserta didik yang telah dkirim oleh orangtua dari masing-masing anak. Mengenai materi kegiatan pembelajaran tetap berpedoman pada Rencana Pelaksanaan Pembelajaran Harian yang telah disusun sebelumnya. Selanjutnya, peneliti melakukan evaluasi dan memberikan penilaian melalui pengamatan terhadap kegiatan pembelajaran yang telah dilakukan dengan mengamati hasil kegiatan peserta didik melalui kiriman video dari orangtua peserta didik sesuai dengan apa yang telah direncanakan sebelumnya.

\section{c. Tahap Observasi Siklus I}

Observasi dilakukan untuk mengumpulkan data pada siklus I yaitu data kemampuan motorik halus anak, pada kegiatan observasi peneliti melakukan pengamatan atau observasi melalui video yang dikirimkan oleh orangtua pada tahap tindakan. Pada tahap ini peneliti akan mengamati perubahan-perubahan pada anak selama kegiatan pembelajaran saat video berlangsung.

Dapat peneliti sampaikan bahwa rata-rata skor kemampuan motorik halus anak melalui kegiatan meronce dari bahan alam biji hanjeli siklus I yaitu 2,4 secara klasikal dan tergolong pada kategori mulai berkembang (MB).

Berikut ini peneliti deskripsikan hasil penilaian kemampuan motorik halus dari masing-masing anak untuk setiap aspek yang diamati.

\section{Tabel 1}

Rekapitulasi Kemampuan Motorik Halus Anak Kelompok A Kober Aulia Melalui Kegiatan Meronce Dari Bahan Alam Biji Hanjeli Pada Siklus I

Tahun Pelajaran 2019/2020

\begin{tabular}{cccc}
\hline No & Kategori Penilaian & Jumlah & Persentase (\%) \\
\hline 1 & Belum Berkembang (BB) & 0 & $0 \%$ \\
\hline 2 & Mulai Berkembang (MB) & 8 & $67 \%$ \\
\hline 3 & Berkembang Sesuai Harapan (BSH) & 4 & $33 \%$ \\
\hline 4 & Berkembang Sangat Baik (BSB) & 0 & $0 \%$ \\
\hline
\end{tabular}

Dari tabel di atas, dapat diuraikan bahwa dari 12 orang anak kelompok A Kober Aulia tidak terdapat anak pada kategori belum berkembang (BB) dengan persentase $0 \%$, terdapat 8 orang anak berada pada kategori mulai berkembang (MB) dengan persentase 67\%, dan 4 orang anak berada pada kategori berkembang sesuai harapan (BSH) dengan persentase 33\%. Artinya, bahwa 4 orang anak atau $33 \%$ anak telah mencapai target perkembangan kemampuan motorik halus anak.

Berdasarkan data tersebut, dapat disimpulkan bahwa kemampuan motorik halus anak setelah kegiatan meronce dari bahan alam biji hanjeli pada siklus I mengalami peningkatan yang cukup baik. Dilihat dari rata-rata skor anak pada 
J-SANAK: Jurnal Kajian Anak

(p-ISSN: 2686-5343 |e-ISSN: 2715-7989)

Vol. (3)(01), (Juli-Desember)(2021), (Halaman)(12-26)

DOI: https://doi.org/10.24127/j-sanak.v3i01.1514

kondii awal mencapai 1,3 yang berada pada kategori belum berkembang(BB), pada siklus I meningkat menjadi 2,4 berada pada kategori mulai berkembang (MB). Dilihat dari persentase anak secara klasikal yang semula pada kondisi awal $0 \%$ yang berarti tidak ada anak yang mencapai target kemampuan motorik halus minimal, pada siklus I terlihat adanya peningkatan sebesar 33\% yang berarti dari 12 orang anak, 4 orang anak telah mencapai target kemampuan motorik halus.

Terlihat kemajuan perkembangan kemampuan motorik halus anak kelompok A Kober Aulia mencapai 0\% pada kategori belum berkembang (BB) dan mengalami peningkatan setelah menggunakan kegiatan meronce dari bahan alam biji hanjeli di data siklus I,33\% pada kategori mulai berkembang (MB). Dengan demikian terjadi kenaikan sebesar $33 \%$ pada kemampuan motorik halus anak.

\section{d. Tahap Refleksi Siklus I}

Berdasarkan pelaksanaan kegitan yang dilaksanakan pada siklus I yang diikuti oleh 12 orang anak kelompok A Kober Aulia terlihat adanya peningkatan yang cukup baik pada kemampuan motorik halus anak dari kondisi awal dengan persentase $0 \%$ yang meningkat menjadi 33\%, namun hal tersebut belum mencapai target yang diharapkan yaitu $85 \%$. Hal ini disebabkan karena dalam proses kegiatan pembelajaran melalui daring sehingga orang tua dan anak melakukan kegiatan masih bingung dan kurang memahami kegiatan yang dilakukan.

Selain faktor anak faktor peneliti pun menjadi faktor yang utama dalam kegiatan pembelajaran anak. Dalam hal ini peneliti kurang berperan dalam proses pelaksanaannya, karena peneliti memiliki ruang gerak sangat kurang bagi keberlangsungan penelitian ini. Adapun perbaikan yang dilakukan sebagain refleksi dari masalah yang berhubungan dengan kemampuan motorik halus anak sebagai berikut.

1. Sebelum memulai kegiatan pembelajaran peneliti memberikan informasi kepada orang tua untuk mempersiapkan dan mengkondisikan anak agar benar-benar siap melakukan kegiatan pembelajaran.

2. Peneliti menyampaikan informasi kepada orang tua untuk memotivasi anak agar ikut dalam kegiatan pada siklus II. Peneliti juga harus menyampaikan kepada orang tua agar lebih aktif mendekati dan membimbing anak. Hal ini dapat memberikan dampak psikologis yang baik untuk anak.

3. Peneliti menyampaikan informasi kepada orang tua agar sebelum memasuki kegiatan pembelajaran, orang tua harus memberikan rasa nyaman. Hal ini akan memudahkan anak dalam mengikuti kegiatan pembelajaran.

Peningkatan kemampuan motorik halus anak kelompok A Kober Aulia Desa Gendereh Kecamatan Buahdua pada pembelajaran kegiatan meronce dari bahan alam biji hanjeli secara klasikal dapat dilihat sebagai berikut. 
J-SANAK: Jurnal Kajian Anak

(p-ISSN: 2686-5343 le-ISSN: 2715-7989)

Vol. (3)(01), (Juli-Desember)(2021), (Halaman)(12-26)

DOI: https://doi.org/10.24127/j-sanak.v3i01.1514

Tabel 2

Peningkatan Kemampuan Motorik Halus Anak Kelompok A Kober Aulia Melalui

Kegiatan Meronce dari Bahan Alam Biji Hanjeli

\begin{tabular}{clccc}
\hline \multirow{2}{*}{ No } & \multicolumn{1}{c}{ Uraian } & \multicolumn{3}{c}{$\begin{array}{c}\text { Peningkatan Kemampuan } \\
\text { Motorik Halus Anak }\end{array}$} \\
\cline { 3 - 5 } & & 1,3 & 2,4 & Sondisi Awal \\
Siklus I & Siklus II \\
\hline 1 & Rata-rata skor seluruh anak & BB & MB & BSB \\
\hline 2 & $\begin{array}{l}\text { Kategori kemampuan motorik } \\
\text { halus seluruh anak }\end{array}$ & $0 \%$ & $33 \%$ & $92 \%$ \\
\hline 3 & $\begin{array}{l}\text { Persentase (\%) anak yang } \\
\text { mencapai kemampuan motorik } \\
\text { halus minimal }\end{array}$ & BB & MB & BSB \\
\hline 4 & $\begin{array}{l}\text { Kategori persentase (\%) anak } \\
\text { yang mencapai kemampuan } \\
\text { motorik halus }\end{array}$ & & & \\
\hline
\end{tabular}

Peningkatan kemampuan motorik halus anak melalui kegiatan meronce dari bahan alam biji hanjeli pada kondisi awal, siklus I dan siklus II dapat digambarkan dalam grafik sebagai berikut.

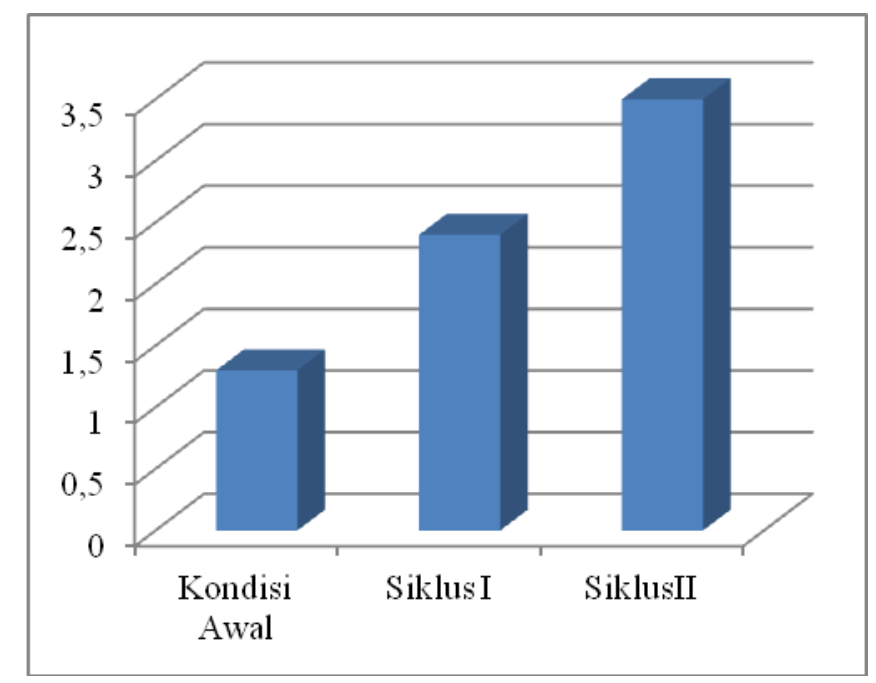

Grafik 1

Diagram Batang Peningkatan Rata-rata Skor Kemampuan Motorik Halus Anak Melalui Kegiatan Meronce dari Bahan Alam Biji Hanjeli Pada Kondisi Awal, Siklus I dan Siklus II

Berdasarkan gambar diagram batang tersebut capaian kemampuan motorik halus anak pada kondisi awal yaitu 1,3 yang berada pada kategori belum berkembang (BB), pada siklus I meningkat menjadi 2,4 yang berada pada kategori mulai berkembang (MB), dan memiliki selisih peningkatan dari kondisi awal ke 
J-SANAK: Jurnal Kajian Anak (p-ISSN: 2686-5343 le-ISSN: 2715-7989)

Vol. (3)(01), (Juli-Desember)(2021), (Halaman)(12-26)

DOI: https://doi.org/10.24127/j-sanak.v3i01.1514

siklus I sebesar 1,1. Pada siklus II meningkat menjadi 3,5 yang berada pada kategori berkembang sangat baik (BSB), dan memiliki selisih peningkatan dari siklus I ke siklus II sebesar 1,1 sedangkan dari kondisi awal ke siklus II sebesar 2,2 .

Peningkatan yang terjadi pada kemampuan motorik halus anak pun dapat dilihat dari persentase anak yang mencapai target kemampuan 23otoric halus anak, pada diagram batang berikut.

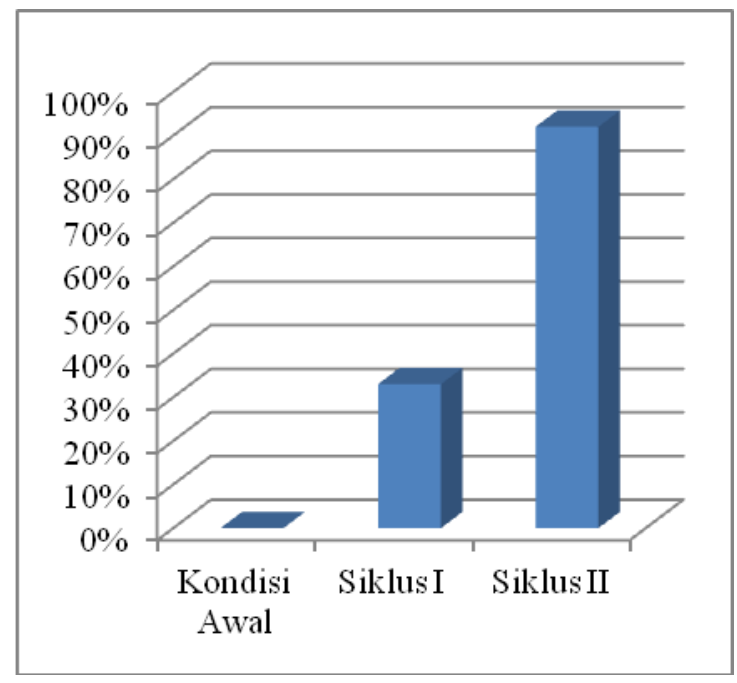

Grafik 2

Diagram Batang Peningkatan Persentase Kategori Anak Mencapai Target

Kemampuan Motorik Halus Minimal Melalui Kegiatan Meronce dari Bahan Alam Biji Hanjeli Pada Kondisi Awal, Siklus I dan Siklus II

Berdasarakan gambar diatas persentase peningkatan kemampuan motorik halus anak melalui kegiatan meronce dari bahan alam biji hanjeli dapat disimpulkan bahwa, pada kondisi awal tidak ada anak yang mencapai target kemampuan motorik halus anak minimal, sehingga persentasenya $0 \%$. Pada siklus I meningkat menjadi $33 \%$ yang mencapai target kemampuan motorik halus, atau dari 12 orang anak sekitar 4 orang anak yang telah mencapai target kemampuan motorik halus anak. Hal tersebut dapat diartikan, bahwa dari kondisi awal ke siklus I mengalami peningkatan sebanyak 33\%. Pada siklus II mengalami peningkatan yang lebih baik lagi, anak yang mencapai target kemampuan motorik halus sebanyak 11 orang anak dan mencapai persentase 92\%, artinya peningkatan yang terjadi dari siklus I ke siklus II sebanyak 59\%. Dengan adanya peningkatan kemampuan motorik halus anak melalui kegiatan meronce dari bahan alam biji hanjeli pada anak kelompok A Kober Aulia Desa Gendereh Kecamatan Buahdua Kabupaten Sumedang tahun pelajaran 2019/2020. Hasil akhir dari siklus II menunjukan persentase yang mencapai target perkembangan kemampuan motorik 
halus anak adalah 92\%, dengan rata-rata skor secara klasikal mencapai 3,5 dengan kategori berkembang sangat baik (BSB).

Hasil penelitian berupa Penggunaan bahan alam biji hanjeli dalam kegiatan meronce ternyata dapat meningkatkan kemampuan motorik halus anak kelompok A Kober Aulia dengan hasil yang cukup siginifikan. Hal itu dibuktikan dengan adanya peningkatan kemampuan motorik halus anak setelah proses pembelajaran melalui kegiatan meronce dari bahan alam biji hanjeli dari perbandingan data awal, siklus I, dan siklus II.

Hal tersebut di atas telah terbukti dengan adanya peningkatan kemampuan mototik halus anak melalui kegiatan meronce dari bahan alam biji hanjeli pada anak kelompok A di Kober Aulia Desa Gendereh Kecamatan Buahdua Kabupaten Sumedang tahun pelajaran 2019/2020. Hasil akhir pada siklus II menunjukan persentase yang mencapai target kemampuan motorik halus adalah 92\%, dengan rata-rata skor kemampuan motorik halus anak secara klasikal mencapai 3,5 dengan kategori berkembang sangat baik (BSB).

Berdasarkan hasil tersebut dapat disimpulkan bahwa hipotesis yang diajukan oleh peneliti dapat diterima, yang artinya melalui kegiatan meronce dari bahan alam biji hanjeli kemampuan motorik halus anak kelompok A Kober Aulia Desa Gendereh Kecamatan Buahdua Kabupaten Sumedang tahun pelajaran 2019/2020 dapat ditingkatkan.
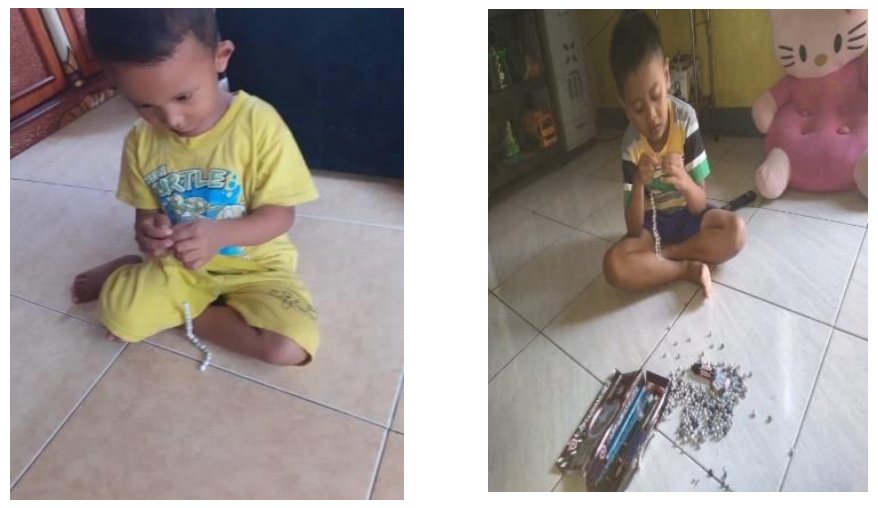

Gambar 3

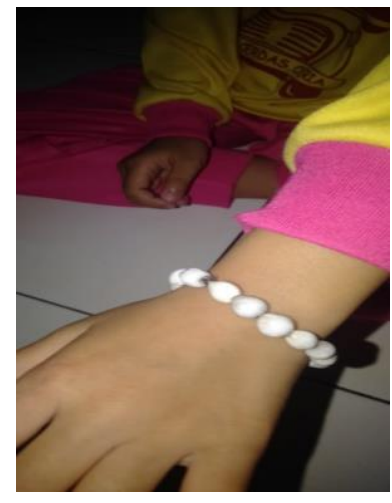

Anak sedang meronce dengan biji hanjeli

\section{PEMBAHASAN}

Berdasarkan hasil penelitian dengan metode pemelitian tindakan kelas dapat disimpulkan bahwa pelaksanaan pembelajaran dengan menggunakan kegiatan meronce dari bahan alam biji hanjeli dapat meningkatkan kemampuan motorik halus anak di kelompok A Kober Aulia Kecamatan Buahdua Kabupaten Sumedang tahun pelajaran 2019/2020. Hal tersebut dapat dilihat dari data kondsi awal untuk rata-rata skor anak yaitu 1,3 yang kategori kemampuan motorik halus yaitu belum berkembang (BB), dan persentase anak yang mencapai kemampuan 
J-SANAK: Jurnal Kajian Anak

(p-ISSN: 2686-5343 |e-ISSN: 2715-7989)

Vol. (3)(01), (Juli-Desember)(2021), (Halaman)(12-26)

DOI: https://doi.org/10.24127/j-sanak.v3i01.1514

motorik halus minimal hanya $0 \%$ dan kategori persentase anak yaitu belum berkembang (BB), namun setelah dilakukan tindakan kelas dengan menggunakan kegiatan meronce dari bahan alam biji hanjeli, kemammpuan motorik halus anak meningkat disetiap siklusnya, yaitu siklus I rata-rata skor anak yaitu 2,4 yang kategorinya mulai berkembang (MB) dan persentase yang mencapai kemampuan motorik halus minimal yaitu 33\% yang kategorinya mulai berkembang (MB), dan peningkatan pada siklus II rata-rata skor anak yaitu 3,5 yang kategorinya berkembang sangat baik (BSB) dan persentase anak yang mencapai kemampuan motorik halus minimal yaitu $92 \%$ secara klasikal yang kategorinya berkembang sangat baik (BSB).

\section{KESIMPULAN}

Berdasarkan hasil penelitian tindakan kelas ini adalah melalui kegiatan meronce dari bahan alam biji hanjeli kemampuan motorik halus anak kelompok A Kober Aulia Desa Gendereh Kecamatan Buahdua Kabupate Sumedang tahun pelajaran 2019/2020 dapat ditingkatkan.

Hal tersebut di atas telah terbukti dengan adanya peningkatan kemampuan mototik halus anak melalui kegiatan meronce dari bahan alam biji hanjeli pada anak kelompok A di Kober Aulia Desa Gendereh Kecamatan Buahdua Kabupaten Sumedang tahun pelajaran 2019/2020. Hasil akhir pada siklus II menunjukan persentase yang mencapai target kemampuan motorik halus adalah $92 \%$, dengan rata-rata skor kemampuan motorik halus anak secara klasikal mencapai 3,5 dengan kategori berkembang sangat baik (BSB) Saran yang dapat disampaikan berdasarkan hasil penelitian yaitu sebagai orang yang berperan dalam proses belajar mengajar di sekolah khususnya guru PAUD hendaknya membuat rencana pembelajaran yang sesuai dengan karakteristik anak dan kreatif juga menarik bagi anak supaya anak tidak bosan dan bersemangat mengikuti pembelajaran di kelas selain itu guru hendaknya membuat kegiatan pembelajaran yang dapat meningkatkan kemampuan motorik halus anak. Hasil penelitian sebaiknya menjadi penentu dalam menentukan program pembelajaran di Kober Aulia Kecamatan Buahdua Kabupaten Sumedang. Sebaiknya sekolah perlu memiliki cara untuk meningkatkan kemampuan motorik halus anak, karena kemampuan motorik halus anak berpengaruh pada kehidupan anak selanjutnya.

Bagi peneliti selanjutnya diharapkan bagi peneliti lain yang ingin menggunakan kegiatan meronce dari bahan alam biji hanjeli supaya lebih kreatif dan inovatif dalam mengembangkan potensi kemampuan anak selain kemampuan motorik halus, sehingga aspek perkembangan anak yang lain berkembang.

\section{E. DAFTAR PUSTAKA}

Arikunto Suharsima. dkk. (2006). Penelitian Tindakan Kelas. Bumi Aksara. Depdiknas. (2014). Permendikbud RI Nomor 137 Tahun 2014 Standar Nasional 
Pendidikan Anak Usia Dini. Depdiknas.

Hajar Pamadhi, E. S. S. (2010). Seni Keterampilan Anak. In Modul Kuliah. Universitas Terbuka.

Muftichatul Daroyah1), M. Thoha BS. Jaya2), M. S. (n.d.). No Ti. FKIP UNILA. http://jurnal.fkip.unila.ac.id/index.php/PAUD/article/download/16874/12054

Mujdito. (2007). Pedoman Bidang Pengembangan Seni di TK.

Mulyasa. (2014). Manajemen PAUD (1st ed.). Remaja Rosdakarya.

Rahman S. (2002). Konsep Desar Pendidikan Anak Usia Dini. PGTKI PRESS

Rilia D. (n.d.). Tahap Tahap anak dalam meronce. 2012.

Rini. (2018). Buku Panduan Pendidik Teknik Meronce untuk PAUD. Bukit Mas Mulia.

Samsudin. (2007). Pembelajaran Motorik di Taman Kanak-kanak. Prenada Media Group.

Sujiono, dkk. (2018). . Metode Pengembangan Fisik. Universitas Terbuka.

Sumantri. (2005). Model Pengembangan Motorik Anak Usia Dini. Depdiknas.

Yani Mulyani dan Juliska Gracinia. (2007). Mengembangkan kemampuan Dsar BALITA di Rumah Kemampuan Fisik, Seni, dan Manajemen Diri. :PT. Elex Media Komputindo.

Yuriastien, E. (2009). Games Therapy untuk Kecerdasan Bayi dan Balita. PT Wahyu Media. 